Article

\title{
Modeling Woody Biomass Procurement for Bioenergy Production at the Atikokan Generating Station in Northwestern Ontario, Canada
}

Md. Bedarul Alam ${ }^{1, *}$, Reino Pulkki ${ }^{1,2}$, Chander Shahi ${ }^{1}$ and Thakur Upadhyay ${ }^{1}$

1 Faculty of Natural Resources Management, Lakehead University, 955 Oliver Road, Thunder Bay, Ontario P7B 5E1, Canada; E-Mails: rpulkki@lakeheadu.ca (R.P.); cshahi@lakeheadu.ca (C.S.); tpupadhy@lakeheadu.ca (T.U.)

2 Department of Forest and Wood Science, Faculty of AgriSciences, Stellenbosch University, Matieland 7602, South Africa

* Author to whom correspondence should be addressed; E-Mail: mbalam@lakeheadu.ca; Tel.:+1-807-343-8221; Fax: +1-807-343-8116.

Received: 6 August 2012; in revised form: 15 November 2012 / Accepted: 23 November 2012 / Published: 3 December 2012

\begin{abstract}
Efficient procurement and utilization of woody biomass for bioenergy production requires a good understanding of biomass supply chains. In this paper, a dynamic optimization model has been developed and applied to estimate monthly supply and procurement costs of woody biomass required for the Atikokan Generating Station (AGS) in northwestern Ontario, based on its monthly electricity production schedule. The decision variables in the model are monthly harvest levels of two types of woody biomass, forest harvest residues and unutilized biomass, from 19,315 forest depletion cells (each $1 \mathrm{~km}^{2}$ ) for a one year planning horizon. Sixteen scenarios are tested to examine the sensitivity of the cost minimization model to changing economic and technological parameters. Reduction in moisture content and improvement of conversion efficiency showed relatively higher reductions in monthly and total costs of woody biomass feedstock for the AGS. The results of this study help in understanding and designing decision support systems for optimal biomass supply chains under dynamic operational frameworks.
\end{abstract}

Keywords: forest cells; logistics cost; optimization; road network; supply chain management 


\section{Introduction}

Biomass has great potential to be converted into renewable bioenergy, which not only has the advantage of reducing greenhouse gas (GHG) emissions, but also ensures a sustainable supply of energy [1-6]. In addition, replacing fossil fuels with bioenergy provides an excellent opportunity to develop energy security and increases rural economic activities [7]. In this context, the Ontario Government has set an ambitious plan for the Atikokan Generating Station (AGS) in northwestern Ontario (NWO) to replace lignite coal with renewable woody biomass as feedstock by 2014. The AGS is located $190 \mathrm{~km}$ west of Thunder Bay. Figure 1 shows the location of AGS and Thunder Bay, with respect to the surrounding forest management units (FMUs) and road network (classified in variable transport cost zones) [8]. The AGS presently utilizes lignite coal and operates at 30\% of capacity [9]. The AGS has a full capacity of $230 \mathrm{MW}$ of electricity production [10,11]. In order to assess the economic feasibility of bioenergy production at the AGS, it is important to understand and improve the efficiency of the woody biomass supply chain from the forest management units (FMUs) surrounding it.

Figure 1. Locations of the City of Thunder Bay and Atikokan Generating Station (AGS) with respect to forest management units and road network (classified in variable transport cost zones) in northwestern Ontario.

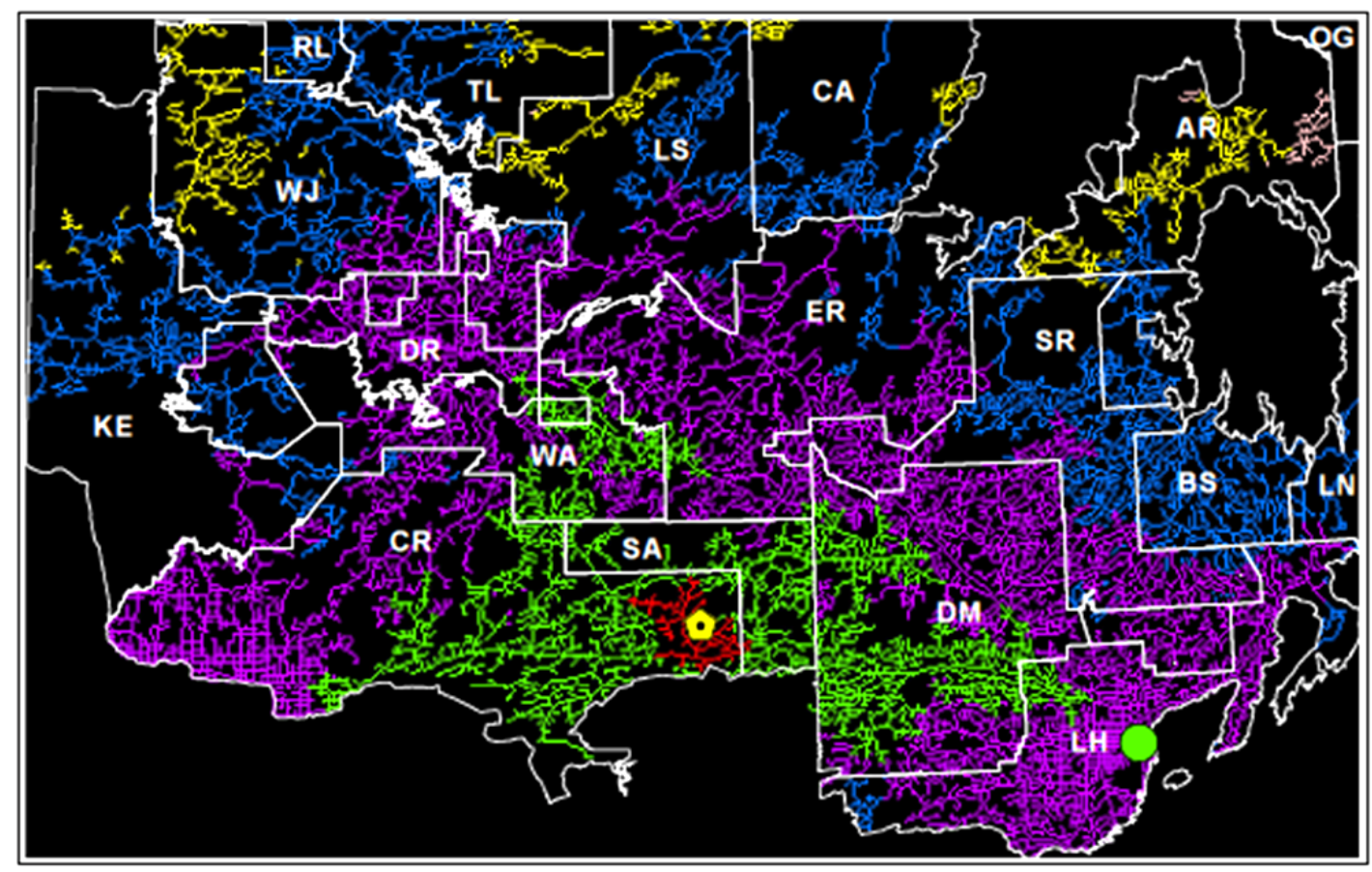

\section{Legend}

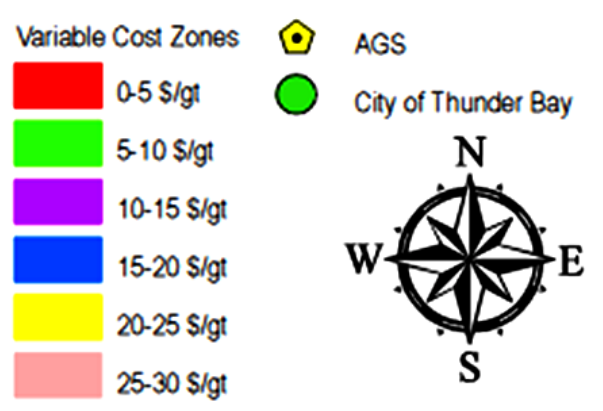

Forest Management Units

$$
\begin{aligned}
& A R=\text { Armstrong Forest } \\
& B S=\text { Black Sturgeon Forest } \\
& C A=\text { Carbou Forest } \\
& C R=\text { Crossroute Forest } \\
& D M=\text { Dog River-Matawin Forest } \\
& D R=\text { Dryden Forest } \\
& E R=\text { English River Forest } \\
& K E=\text { Kenora Forest } \\
& L S=\text { Lac Seul Forest } \\
& L N=\text { Lake Nipigon Forest } \\
& L H=\text { Lakehead Forest }
\end{aligned}
$$

$$
\begin{aligned}
& O G=\text { Ogoki Forest } \\
& R L=\text { Red Lake Forest } \\
& S A=\text { Sapawe Forest } \\
& S R=\text { Spruce River Forest } \\
& T L=\text { Trout Lake Forest } \\
& W A=\text { Wabigoon Forest } \\
& W J=\text { Whiskey Jack Forest }
\end{aligned}
$$

Map Projection: UTM, Zone 15, NAD83 Map Prepared By: Md. Bedarul Alam Dated: July 9, 2012 
There has been little published research on improving the efficiency of woody biomass supply chains [12], due to the lack of availability of real data and appropriate methodologies for assessing woody biomass availability [12]. A few studies, that address the biomass supply chain management problem in the forestry sector, have only focused on a single aspect of the problem [13,14]. For example, supply chain management studies related to the pulp industry focus specifically on harvesting, transportation of pulpwood, production scheduling and distribution of pulp to customers [15].

The recent interest in the bioenergy sector has resulted in the development of location and problem specific models for optimization of woody biomass collection [16-21]. For example, Rentizelas et al. [21] developed a model for a multi-biomass supply chain for a tri-generation facility to maximize financial benefits by reducing costs, warehousing requirements and capital costs. Tri-generation refers to the simultaneous production of power, heat and cooling from one plant. A study in Massachusetts investigated the GHG implications of switching over from fossil fuel sources to woody biomass feedstock for energy production, as well as the availability of woody biomass in forests to support biomass based energy production, the potential ecological impacts of increased biomass harvesting, and the importance of policies to ensure harvesting biomass sustainably [22]. However, these studies used a linear programming (LP) approach for designing a biomass supply system (harvesting, storing and transporting) for a centrally located plant [23]. LP models have also been used to optimize (minimize) the overall energy cost for biomass-based combined cooling, heating and power generation (CCHP) systems [24,25]. The problem with the LP modeling approach is that it over-simplifies complex problems into simple linear equations and cannot optimize problems where decision variables are constrained to have only integer values. In order to account for both discrete as well as continuous decision variables for optimizing supply logistics, mixed-integer programming (MIP) models are used [12,26-28]. The use of MIP models in bioenergy production has been further extended by formulating mixed integer linear programming (MILP) models to optimize the design of supply networks based on financial criteria [29,30]. However, even the MIP and MILP models do not account for all real life uncertainties encountered in complex and difficult woody biomass-based energy production systems, mainly due to over-simplified linearity assumptions [31]. The real life uncertainties can refer to the distribution and availability of woody biomass in the forest area. Each cell in the forest area can have varying distribution and amount of biomass, which cannot be accounted for in LP optimization models. In addition, MIP and MILP models cannot account for more than one outcome, making it difficult or sometimes impossible to describe future possible outcomes.

To overcome the limitations of LP, MIP and MILP models, a non-linear dynamic programming (NLDP) approach is more appropriate because it can solve a problem by taking into account real world uncertainties over a time horizon: e.g., different types of biomass availabilities in the forests in different months over a one year time horizon. A few NLDP models have been developed for harvesting and transporting agricultural residue for bioenergy production in different parts of the world: United States [32-34], Brazil [35], Netherlands [36,37] and Europe [38]. Studies in Canada mostly focused on optimizing harvesting and transportation of raw material for forest products industries [12,39-43]. Since woody biomass is usually scattered over a large geographic area, its supply chain modeling requires accurate information about its location and availability [44,45]. Also, biomass demand can vary considerably between months and by season depending on energy demand. 
Therefore, the integration of geographic information systems (GIS) with NLDP is necessary for supplying woody biomass from different geographic areas to a power plant over a time horizon. GIS is a versatile tool that helps in capturing, managing, analyzing and displaying all forms of geographically referenced information in a systematic way. GIS models have been used to solve biorefinery location problems [46], planning logistics of bioenergy production using forest and agricultural biomass, as well as industrial and urban wood wastes [47], and for transportation network analysis [48]. GIS can also be used together with mathematical programming methods to develop an integrated model for supplying woody biomass for energy production [17,46,49-53] by integrating spatial and aspatial data to solve location specific and real time problems.

The innovative and original contribution of this paper is to develop a GIS-based integrated NLDP model for procuring woody biomass for the AGS from surrounding FMUs in the most economical and sustainable way. The specific objectives are: (i) to determine the type and quantity of woody biomass, from forest cells (each of $1 \mathrm{~km}^{2}$ size), supplied to the AGS over a one year horizon based on monthly electricity production; (ii) to compute the optimized monthly woody biomass procurement costs; and (iii) to perform sensitivity analyses for examining the effect of key parameters on woody biomass feedstock supply costs. Modeling woody biomass procurement at the AGS is the first optimization model developed for bioenergy production in Ontario. Although, this model has been specifically developed for the AGS, it is applicable for optimizing the feedstock procurement of any biomass-based power plant provided the data for supply of different kinds of biomass and road network are available.

\section{Methodology}

The flow chart in Figure 2 presents the methodology for supplying woody biomass to the AGS at minimum cost using the GIS-based integrated NLDP model. The study area, $324 \mathrm{~km}(\mathrm{~N}-\mathrm{S}) \times 516 \mathrm{~km}$ (E-W) $\left(167,184 \mathrm{~km}^{2}\right)$, consists of 18 FMUs surrounding the AGS [45]. GIS data were collected from Land Information Ontario, Sustainable Forest License (SFL) holders and consultant companies in the formats of Shapefile and Geodatabase [54-57]. The original vector data was first converted to raster and finally to spatial database ASCII (.txt) files for the entire research area using ArcGIS software. Three main spatial layers (land use, forest depletion and cost layers) were prepared on a raster grid size of $1 \mathrm{~km} \times 1 \mathrm{~km}\left(1 \mathrm{~km}^{2}\right)$, where each cell represents a feature [58,59]. Different data input methods were followed for different types of features. The dominant data input method was used to create a raster layer of forest land use class [59]. In this method, a grid code entity $(1$ = productive forest, $2=$ water/lake, and $3=$ other land use) is assigned to each feature, which occupies more than $50 \%$ of the cell area [45].

The percent occurrence method is used to prepare the depletion layer. In this method, a code number is assigned to the grid cell depending on its depletion percentage (percent of the cell area harvested, where, 1 is $100 \%, 2$ is from $80 \%$ to $100 \%, 3$ is from $60 \%$ to $80 \%, 4$ is from $40 \%$ to $60 \%$, 5 is from $20 \%$ to $40 \%, 6$ is from more than $0 \%$ to $20 \%$ depletion and 7 is no depletion) [45]. Before developing the marginal transport cost layer for the AGS, a raster layer of the road network for the research area was developed using the presence/absence method of data input $[8,59]$. A grid code was assigned depending on the presence of different types of roads ( 1 = highway-I, 2 = highway-II, and 
$3=$ primary, $4=$ secondary and $5=$ tertiary/operational forest roads and $9=$ no road) in a cell. The raster layer of the road network was converted to ASCII (.txt) format.

Figure 2. Flow chart for supplying woody biomass to the AGS at minimum cost using the GIS-based integrated NLDP model.

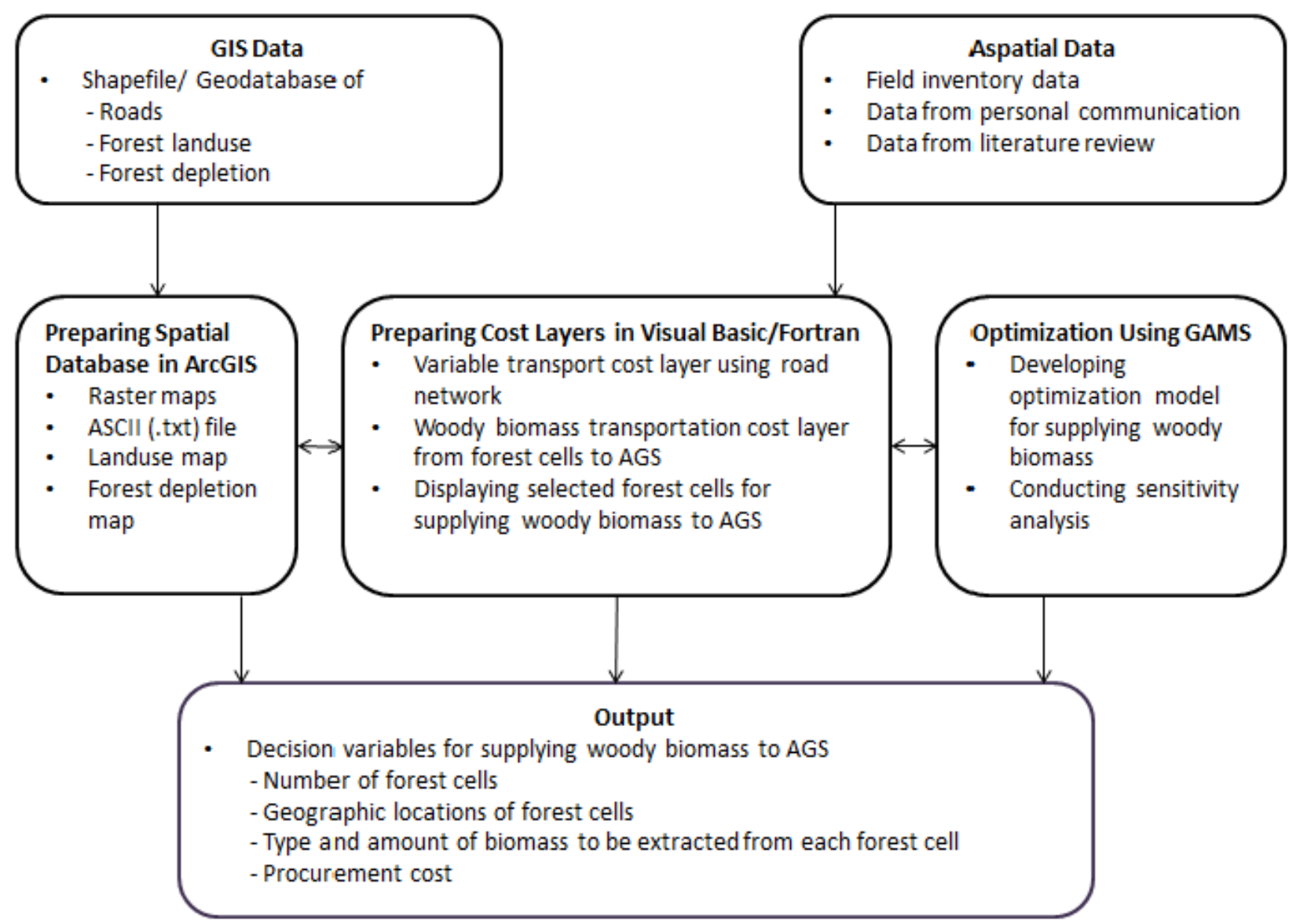

Visual Basic software was used to prepare the minimum cost layer for transporting woody biomass through the road network to the AGS (Figures 1 and 2). The location of the AGS was used as the sink node during the data input and optimization processes. The driving speeds of $(90,80,60,40$ and $\left.30 \mathrm{~km} \cdot \mathrm{h}^{-1}\right)$ for an empty vehicle and $\left(90,70,50,30\right.$ and $\left.20 \mathrm{~km} \cdot \mathrm{h}^{-1}\right)$ for a loaded vehicle were used on highway-I, highway-II, and primary, secondary and tertiary/operational forest roads, respectively. The vehicle considered for transporting woody biomass feedstock is a tractor with a 53 foot semi-trailer (with belly). In Ontario, the allowable legal payload weight for this type of tractor-trailer is taken as 40.55 tonnes $(\mathrm{t})$ (this will vary depending on tractor and trailer tare weight) [60]. The charge-out rate for a biomass truck with operator is assumed to be $85 \$ \cdot h^{-1}$ (2009 based). A fixed time for loading, unloading and delay of $2.5 \mathrm{~h}$ per trip is assumed. In this cost layer, the cost of transporting woody biomass from each road cell $\left(1 \mathrm{~km}^{2}\right)$ of the research area to the AGS was established.

The NLDP model was developed using GAMS software. Forest land use, depletion and cost layers were used to establish the cost of transporting woody biomass from each productive forest cell to the AGS. Along with cost data, other relevant parameters were used to feed the model in GAMS. The woody biomass feedstock is available in two product forms (forest harvest residues (FHR) and underutilized wood (UW)) from the surrounding 18 FMUs. FHR constitute leftover tops, branches and 
other parts of trees harvested mainly for the lumber, and pulp and paper industries $[61,62]$. UW are the tree species and unmerchantable wood, which are not considered commercially important, and trees damaged by wildfire, windthrow and insects that are currently not salvaged. The theoretical availability of FHR and UW from the productive forests of the study area was estimated at $60 \mathrm{~m}^{3} \cdot \mathrm{ha}^{-1}$ each [45]. A pre-harvest inventory conducted by Alam et al. in the Crossroute Forest found the UW volume to be $65 \mathrm{~m}^{3} \cdot \mathrm{ha}^{-1}$ [45]. However, only $36 \%$ of trees, which constitute $38 \%$ wood volume, fall under the UW category. Therefore, Alam et al. conservatively estimated the average theoretical UW availability as $60 \mathrm{~m}^{3} \cdot \mathrm{ha}^{-1}$ [45]. Reynolds et al. found similar results in their study in the Black Sturgeon Forest, where $43 \%$ of trees were under the UW category [63]. The theoretical availability of FHR and UW in depleted cells, was calculated on the basis of depletion percentages: e.g., in a cell with $100 \%$ depletion there is $6000 \mathrm{~m}^{3} \mathrm{FHR}$ and no UW, in a cell with $90 \%$ depletion there is $5400 \mathrm{~m}^{3} \mathrm{FHR}$ and $600 \mathrm{~m}^{3} \mathrm{UW}$, and in a cell with no depletion there is no FHR. In addition, no UW is planned for harvesting from the forest cell with $0 \%$ depletion.

The number of depleted forest cells over a historical seven-year period (2002-2009) was found to be 19,315 cells. We also assumed that $1 \mathrm{~m}^{3}$ woody biomass weighs 0.876 green tonne (gt) $[45,64,65]$. The two-way travel times (hours) and transportation costs $\left(\$ \cdot \mathrm{gt}^{-1}\right)$ of woody biomass from all $(19,315)$ depleted forest cells of $1 \mathrm{~km}^{2}$ size to the AGS were determined using the road network optimization model [8]. The NLDP model then selects the optimal harvest of forest cells in order to meet the feedstock requirements for the given monthly production schedule, and calculates the costs for biomass procurement. The sets, indices, parameters and variables used in this model are as follows:

Sets:

I: Set of woody biomass production and supplying time (12 months)

$J$ : Set of forest cells $(19,315$ cells $)$

\section{Indices:}

$i=$ Woody biomass production and supplying month $(i=1,2,3, \ldots, 12)$

$j=$ Forest cells $(j=1,2,3, \ldots, 19,315)$

\section{Parameters:}

$C E=$ Conversion efficiency of AGS

$E D=$ Energy density of woody biomass $\left(\mathrm{GJ} \cdot \mathrm{ODt}^{-1}\right)$

$M C=$ Moisture content in green biomass (\% green weight basis)

$E G=$ Equivalency of energy $\left(\mathrm{GJ} \cdot \mathrm{MWh}^{-1}\right)$

$E P_{\mathrm{i}}=$ Demand of electricity production of AGS in $i^{\text {th }}$ month (MWh)

$B D_{\mathrm{i}}=$ Total amount (gt) of biomass required by AGS in $i^{\text {th }}$ month, calculated in Equation (1):

$$
B D_{i}=\frac{E P_{i} \times E G}{(E D-0.2164 \times M C) \times C E}
$$

$H F=$ Harvesting factor

$P R=$ Cost $\left(\$ \cdot \mathrm{gt}^{-1}\right)$ of piling and grinding/chipping (processing) of roadside FHR

$P U=\operatorname{Cost}\left(\$ \cdot \mathrm{gt}^{-1}\right)$ of felling and extraction of UW to roadside, and its grinding/chipping at roadside

$P=$ Rate of payment $\left(\$ \cdot h^{-1}\right)$ for woody biomass truck including operator 
$L=$ load size $\left(\mathrm{m}^{3}\right)$ of woody biomass truck

$F=$ Conversion factor for biomass from cubic metre to green tonne

$T_{\mathrm{j}}=$ Variable time to transport woody biomass from a forest cell AGS (h)

$V C_{\mathrm{j}}=$ Variable cost $\left(\$ \cdot \mathrm{gt}^{-1}\right)$ to transport woody biomass from a forest cell to AGS, calculated in Equation (2).

$$
V C_{j}=\frac{T_{j} \times P}{L \times F}
$$

$F T=$ Fixed time $(\mathrm{h})$ for loading, unloading and delay per trip

$F C=$ Fixed cost $\left(\$ \cdot \mathrm{gt}^{-1}\right)$ to transport woody biomass from a forest cell to AGS, calculated in Equation (3).

$$
F C=\frac{F T \times P}{L \times F}
$$

$T C_{\mathrm{j}}=$ Biomass transportation cost $\left(\$ \cdot \mathrm{gt}^{-1}\right)$ from the $j^{\text {th }}$ forest cell to AGS, calculated in Equation (4).

$$
T C_{j}=V C_{j}+F C
$$

$F R_{\mathrm{j}}=$ Theoretical FHR availability (gt) in a forest cell over 7 years horizon (2002-2009)

$F U_{\mathrm{j}}=$ Theoretical UW availability (gt) in a forest cell over 7 years horizon (2002-2009)

$I R_{\mathrm{j}}=$ Initial technical FHR availability (gt) in a forest cell in the 12 months horizon, calculated in Equation (5).

$$
I R_{j}=\frac{\mathrm{FR}_{\mathrm{j}} \times H F}{7}
$$

$I U_{\mathrm{j}}=$ Initial technical UW availability (gt) in a forest cell in the 12 months horizon, calculated in Equation (6).

$$
I U_{j}=\frac{\mathrm{FU}_{\mathrm{j}} \times H F}{7}
$$

\section{Variables:}

$R_{i j}=$ Amount of FHR harvested (gt) in $i^{\text {th }}$ month from $j^{\text {th }}$ forest cell

$U_{i j}=$ Amount of UW harvested (gt) in $i^{\text {th }}$ month from $j^{\text {th }}$ forest cell

$T B_{i}=$ Total amount of biomass harvest in $i^{\text {th }}$ month

$T P C=$ Total biomass procurement $\operatorname{cost}(\$)$

$R T_{i j}=$ Total amount of FHR available (gt) in $i^{\text {th }}$ month from $j^{\text {th }}$ forest cell

$U T_{i j}=$ Total monthly UW available (gt) in $i^{\text {th }}$ month from $j^{\text {th }}$ forest cell

$R T_{(i+1) j}=$ Total amount of FHR available $(\mathrm{gt})$ in $(i+1)^{\text {th }}$ month from $j^{\text {th }}$ forest cell

$U T_{(i+1) j}=$ Total amount of UW available $(\mathrm{gt})$ in $(i+1)^{\text {th }}$ month from $j^{\text {th }}$ forest cell

The objective function is to minimize the overall procurement costs for a given monthly woody biomass demand of the AGS for a one-year time horizon. As this complex problem is formulated as a non-linear dynamic programming problem, the difficulty to solve this type of problem is linked to the combinatorial complexity of the problem, and the solution space increases exponentially with the 
problem size. The objective function and the constraints of the model are described by the following equations:

$$
\text { Minimize } T P C=\sum_{i=1}^{12} \sum_{j=1}^{19315}\left(R_{i j}\left(P R+T C_{j}\right)\right)+\sum_{i=1}^{12} \sum_{j=1}^{19315}\left(U_{i j}\left(P U+T C_{j}\right)\right)
$$

Subject to:

$$
\begin{gathered}
R T_{1 j}=I R_{j} \\
U T_{1 j}=I U_{j} \\
\sum_{j=1}^{19315} R_{i j}+\sum_{j=1}^{19315} U_{i j}=T B_{i} \\
R_{i j} \leq R T_{i j} \\
U_{i j} \leq U T_{i j} \\
R T_{(i+1) j}=R T_{i j}-R_{i j} \\
U T_{(i+1) j}=U T_{i j}-U_{i j} \\
T B_{i} \geq B D_{i} \\
R_{i j}, U_{i j} \geq 0
\end{gathered}
$$

Equation (7) is the objective function of the model, which minimizes total cost (\$), which is the summation of total cost of piling and grinding/chipping (processing) of roadside FHR, and total cost of felling and extraction of UW to roadside and its grinding/chipping at roadside, and total transportation costs of FHR and UW, respectively. Equations (8) to (16) are the constraints in the model. Equations (8) and (9) specify the constraints that the total amount (gt) of FHR and UW available in $1^{\text {st }}$ month in $j^{\text {th }}$ forest cell is equal to the initial technical FHR and UW availability (gt) in the forest cell, respectively. Equation (10) specifies the constraint that the total amount of biomass procured (gt) in $i^{\text {th }}$ month for the AGS is the sum of the total amount (gt) of FRH and UW harvested from the forest cells in the $i^{\text {th }}$ month. Equations (11) and (12) specify the constraints that the total amount (gt) of FHR and UW harvested is less than or equal to the amount (gt) of FHR and UW available in the $i^{\text {th }}$ month from the $j^{\text {th }}$ forest cell, respectively. Equations (13) and (14) are the availability constraints for FHR and UW, which ensure that the total amount (gt) of FHR and UW available in a forest cell for the next month is equal to the balance of the amount (gt) of FHR and UW in the cell after harvesting FHR and $\mathrm{UW}$, respectively from this cell in the present month. Here, the initial state of the system (e.g., $\left.\mathrm{RT}_{(0)}\right)$ is known. That is, the residue is available at the beginning of the optimization problem, and that it is considered in the known initial state of the system. Equation (15) is the biomass procurement constraint, which confirms that the total amount (gt) of biomass procured in $i^{\text {th }}$ month is greater than or equal to the total amount (gt) of biomass required in $i^{\text {th }}$ month to generate the desired amount of power in this month at AGS. Finally, Equation (16) ensures that the decision variables (amount of FHR and UW harvested) are positive. 
The model becomes non-linear due to the inherent nature of the solution procedure in GAMS, where one endogenous variable (amount of biomass to be harvested in the next period) is determined with the help of another endogenous variable (the amount harvested in the previous periods). The model is dynamic in the sense that it provides a global solution to the entire planning horizon of 12 months of power plant operation by simultaneously taking the capacity constraints and requirements for each month into account.

Table 1 shows the estimates of parameters used in the BASE scenario of the model. The assumptions in the BASE scenario include a harvesting factor of $67 \%$, cost $\left(\$ \cdot \mathrm{gt}^{-1}\right)$ of piling and grinding/chipping (processing) of roadside FHR (PR), and cost $\left(\$ \cdot \mathrm{gt}^{-1}\right)$ of felling and extraction of UW to roadside and its grinding/chipping at roadside (PU) of $\$ 26$ and $\$ 31$, respectively [66], conversion efficiency of power plant of $35 \%$, and moisture content of woody biomass of $40 \%$. The heat value of oven-dry woody biomass is taken as $19.6 \mathrm{GJ} \cdot \mathrm{ODt}^{-1}$ [67], and 3.6 $\mathrm{GJ} \cdot \mathrm{MWh}^{-1}$ are used to convert the heat value to electricity units. Figure 3 shows the monthly power production (MWh) over the one-year planning horizon [9].

Table 1. Estimates of parameters used in BASE scenario of the model.

\begin{tabular}{llll}
\hline Descriptions & Unit & Estimates & Remarks \\
\hline Harvesting and processing costs of FHR & $\$ \cdot \mathrm{gt}^{-1}$ & 26 & Based on Forest BioProducts Inc. [10] \\
Harvesting and processing costs of UW & $\$ \cdot \mathrm{gt}^{-1}$ & 31 & Based on Forest BioProducts Inc. [10] \\
$\begin{array}{l}\text { Fixed cost due to load/unload time, } \\
\text { delays and overhead }\end{array}$ & $\$ \cdot \mathrm{gt}^{-1}$ & 5.24 & Own estimate \\
Charge rate of biomass truck & $\$ \cdot \mathrm{h}^{-1}$ & 85 & Based on Alam et al. [8] \\
Heat value of woody biomass & $\mathrm{GJ} \cdot \mathrm{ODt}^{-1}$ & 19.6 & Based on Hosegood [67] \\
Harvesting factor of FHR & $\%$ of FHR $^{-1}$ & 67 & Based on Alam et al. [45] \\
Harvesting factor of UW & $\%$ of UW & 67 & Based on Alam et al. [45] \\
Moisture content of woody biomass & $\%$ & 40 & Based on Gautam et al. [68] \\
Conversion efficiency of power plant & $\%$ & 35 & Power plant data \\
Number of depleted forest cells & No & 19,315 & Based on Alam et al. [45] \\
\hline
\end{tabular}

Note: $\mathrm{FHR}=$ forest harvest residue; $\mathrm{UW}=$ underutilized wood; $\mathrm{gt}=$ green tonne; $\mathrm{h}=$ hour; $\mathrm{yr}=$ year.

Sixteen alternate scenarios (Table 2) were run to test the sensitivity of the cost minimization model to changes in HF, CE, MC and processing costs (PC) of both FHR and UW. First, the effect of HF was explored, keeping other parameters the same as in the BASE scenario. For example, in HFIA, the HF was increased to $73.7 \%$ (10\% increase compared to the BASE), in HFIB the HF was increased to $80.4 \%$ (20\% increase), in HFDA the HF was decreased to $60.3 \%$ (10\% decrease), and in HFDB the HF was decreased to $53.6 \%$ (20\% decrease). Second, the sensitivity of CE was explored, keeping other parameters the same as in the BASE scenario. In CEIA and CEIB, the CE was increased by $10 \%$ and $20 \%$ respectively, whereas in CEDA and CEDB, the CE was decreased by $10 \%$ and $20 \%$ respectively. Third, the sensitivity of MC was tested by increasing MC by $10 \%$ (MCIA) and $20 \%$ (MCIB), and by decreasing MC by 10\% (MCDA) and 20\% (MCDB). 
Table 2. Description of different scenarios of the model. Numbers in brackets indicate \% change of parameters from the BASE scenario in sensitivity analyses.

\begin{tabular}{|c|c|c|c|c|c|c|c|}
\hline \multirow{2}{*}{ Scenario } & \multicolumn{7}{|c|}{ Key parameters } \\
\hline & HF (\%) & PR $\left(\$ \cdot \mathrm{gt}^{-1}\right)$ & PU $\left(\$ \cdot \mathrm{gt}^{-1}\right)$ & CE (\%) & MC (\%) & ED $\left(G J \cdot O D t^{-1}\right)$ & EG $\left(G J \cdot M W h^{-1}\right)$ \\
\hline BASE & 67 & 26 & 31 & 35 & 40 & 19.6 & 3.6 \\
\hline HFIA & $73.7(+10 \%)$ & 26 & 31 & 35 & 40 & 19.6 & 3.6 \\
\hline HFIB & $80.4(+20 \%)$ & 26 & 31 & 35 & 40 & 19.6 & 3.6 \\
\hline HFDA & $60.3(-10 \%)$ & 26 & 31 & 35 & 40 & 19.6 & 3.6 \\
\hline HFDB & $53.6(-20 \%)$ & 26 & 31 & 35 & 40 & 19.6 & 3.6 \\
\hline CEIA & 67 & 26 & 31 & $38.5(+10 \%)$ & 40 & 19.6 & 3.6 \\
\hline CEIB & 67 & 26 & 31 & $42(+20 \%)$ & 40 & 19.6 & 3.6 \\
\hline CEDA & 67 & 26 & 31 & $31.5(-10 \%)$ & 40 & 19.6 & 3.6 \\
\hline CEDB & 67 & 26 & 31 & $28(-20 \%)$ & 40 & 19.6 & 3.6 \\
\hline MCIA & 67 & 26 & 31 & 35 & $44(+10 \%)$ & 19.6 & 3.6 \\
\hline MCIB & 67 & 26 & 31 & 35 & $48(+20 \%)$ & 19.6 & 3.6 \\
\hline MCDA & 67 & 26 & 31 & 35 & $36(-10 \%)$ & 19.6 & 3.6 \\
\hline MCDB & 67 & 26 & 31 & 35 & $32(-20 \%)$ & 19.6 & 3.6 \\
\hline PCIA & 67 & $28.6(+10 \%)$ & $33(+10 \%)$ & 35 & 40 & 19.6 & 3.6 \\
\hline PCIB & 67 & $31.2(+20 \%)$ & $37.2(+20 \%)$ & 35 & 40 & 19.6 & 3.6 \\
\hline PCDA & 67 & $23.4(-10 \%)$ & $27.9(-10 \%)$ & 35 & 40 & 19.6 & 3.6 \\
\hline PCDB & 67 & $20.8(-20 \%)$ & $24.8(-20 \%)$ & 35 & 40 & 19.6 & 3.6 \\
\hline
\end{tabular}

Note 1: $\mathrm{HF}=$ Harvesting factor; $\mathrm{PR}=\mathrm{Cost}\left(\$ \cdot \mathrm{gt}^{-1}\right)$ of piling and grinding/chipping (processing) of roadside forest harvest residue $(\mathrm{FHR}) ; \mathrm{PU}=\mathrm{Cost}\left(\$ \cdot \mathrm{gt}^{-1}\right)$ of felling and extraction of $\mathrm{UW}$ to roadside, and its grinding/chipping at roadside; $\mathrm{CE}=$ Conversion efficiency of Atikokan Generating Station $(\mathrm{AGS})$; $\mathrm{MC}=\mathrm{Moisture}$ content in green biomass (\% green weight basis); $\mathrm{ED}=$ Energy density of woody biomass $\left(\mathrm{GJ}^{\mathrm{O}} \mathrm{ODt}^{-1}\right)$; and $\mathrm{EG}=$ Equivalency of energy $\left(\mathrm{GJ} \cdot \mathrm{MWh}^{-1}\right)$.

Note 2: Abbreviation of different scenarios of the model - BASE = Business as usual scenario of the model, and in other scenarios the parameter values change in relation with this base scenario; HFIA = In this scenario HF increased by $10 \%$ from BASE scenario; HFIB $=$ HF increased by $20 \%$; HFDA $=$ HF decreased by $10 \%$; HFDB $=$ HF decreased by $20 \%$; CEIA $=\mathrm{CE}$ increased by $10 \%$; CEIB $=\mathrm{CE}$ increased by $20 \%$; CEDA $=\mathrm{CE}$ decreased by $10 \%$; $\mathrm{CEDB}=\mathrm{CE}$ decreased by $20 \%$; $\mathrm{MCIA}=\mathrm{MC}$ increased by $10 \%$; MCIB $=$ MC increased in $20 \%$; MCDA $=$ MC decreased by $10 \%$; MCDB $=$ MC decreased by $20 \%$; PCIA $=$ PR and PU increased by $10 \%$; PCIB $=$ PR and PU increased by $20 \%$; PCDA = PR and PU decreased by $10 \%$; PCDB = PR and PU decreased by $20 \%$. 
Finally, the effect of PC was tested by increasing PC by $10 \%$ (PCIA) and $20 \%$ (PCIB), and by decreasing $\mathrm{PC}$ by $10 \%$ (PCDA) and 20\% (PCDB) (Table 2). The results are displayed in ODt to eliminate the effect of moisture content.

Figure 3. Monthly power production schedules at the AGS. The bars represent actual monthly power production in 2010 at the AGS to meet electricity demands [9].

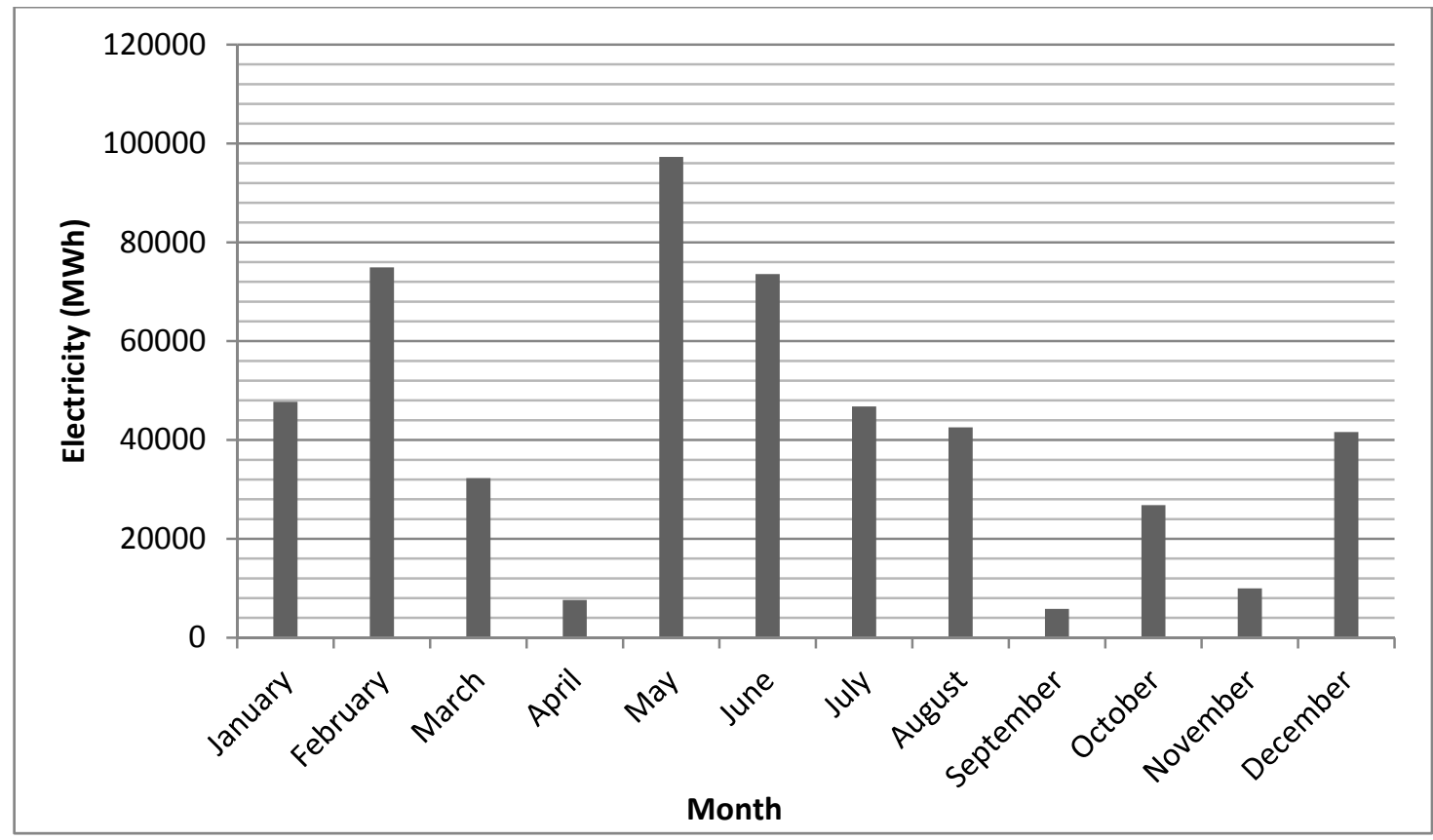

\section{Results and Discussion}

The model provides a global optimal solution over a one-year planning horizon by minimizing the objective function of biomass procurement costs (including harvesting, processing and transportation) based on woody biomass availability in each cell and monthly biomass demand based on electrical power production requirements. In the BASE scenario, out of 19,315 forest cells, the model selects 3097 cells for harvesting FHR and 377 cells for harvesting UW to fulfill the annual woody biomass demand for the AGS (Figure 4). The forest cells selected for collecting FHR are mainly located in the following five FMUs: Crossroute Forest, Sapawe Forest, Dog River-Matawin Forest, Wabigoon Forest and Dryden Forest (Figure 4). Only two forest cells from the Lakehead Forest are selected for FHR (Figure 4). All forest cells selected for harvesting UW are located in the Crossroute Forest (Figure 4). Out of 18 FMUs (Figure 1), 12 FMUs are not selected to harvest woody biomass for energy production (Figure 4). The selected forest cells are located near the AGS and in lower cost zones (Figures 1 and 4). Depending on the monthly production schedule at the AGS (Figure 3), the optimal amount of woody biomass harvesting required for each month is illustrated in Figure 5. The total monthly amount of woody biomass harvested ranges from 3283 ODt (September) to 54,857 ODt (May). The average monthly amount of woody biomass harvested is 23,827 ODt. 
Figure 4. Selected forest cells to harvest FHR and UW for the AGS (BASE Scenario).

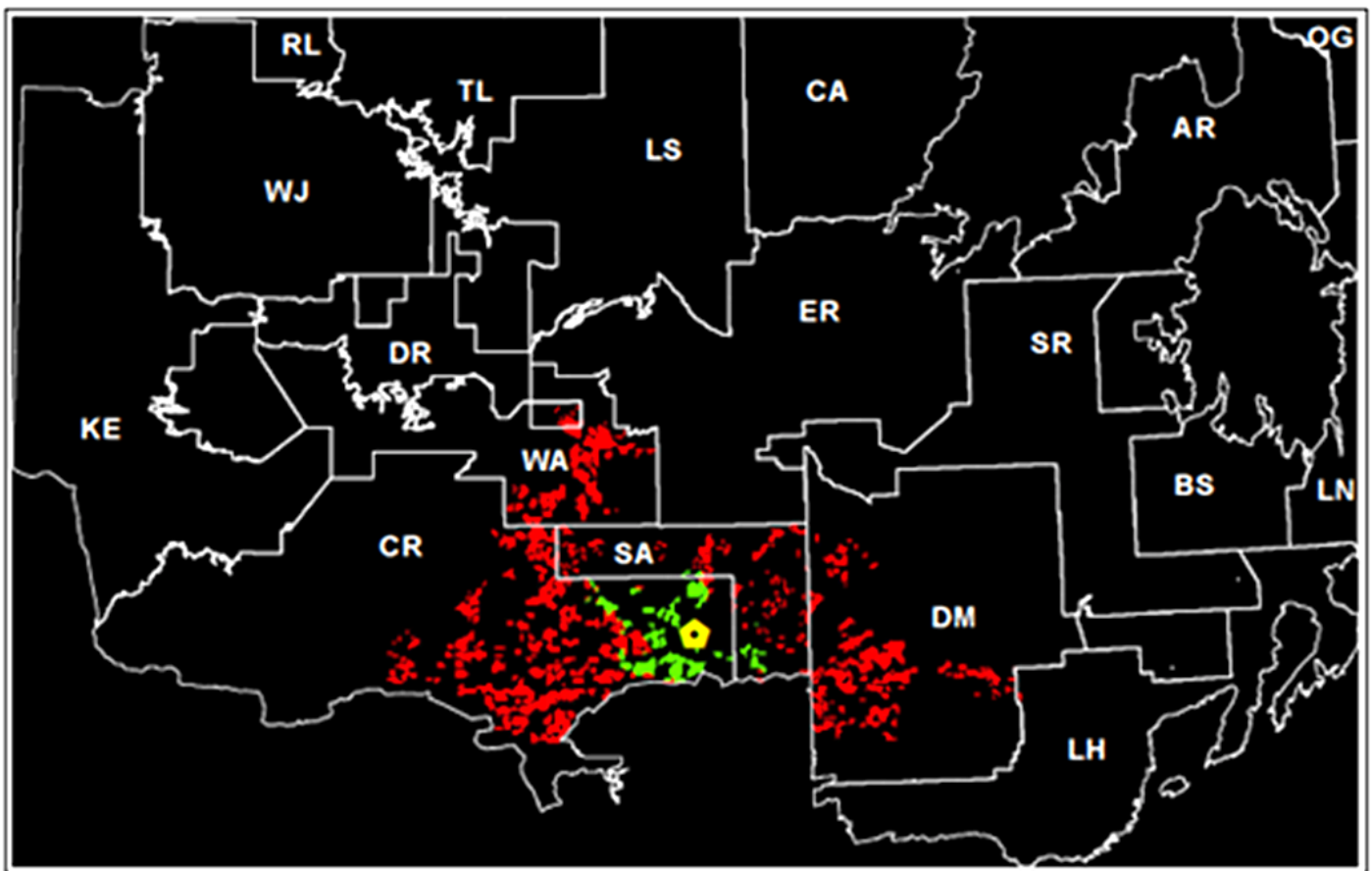

\section{Legend}

Selected Forest Cels

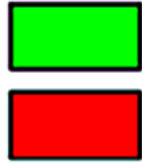
FHR and UW FHR

Power Plant

- AGS
Forest Management Unts

$A R=$ Armstrong Forest $B S=$ Black Sturgeon forest $C A=$ Carbou Forest

$C R=$ Crossrouse Forest

$D M=$ Dog River $\cdot$ Matawin Forest

$D R=$ Dryden Forest

$E R=$ English $R$ iver forest

$K E=$ Kenora Forest

LS - Lac Seul Forest

$\mathrm{UN}=$ Lake Noigon Forest

$\mathrm{LH}=$ Lakehead Forest
$O G=$ Ogoki Forest

$\mathrm{RL}=$ Red Lake Forest

$S A=$ Sapawe Forest

$S R=$ Spruce River Forest

$\mathrm{TL}=$ Trou L Lake Forest

$W A=$ Wabigoon Focest

$W J=$ Whiskey Jack Forest

Map Projection UTM, Zone 15. NADB3

Map Prepared By. Md Bedarul Alam

Dated June 27. 2011

Figure 5. Monthly amount of woody biomass consumption at the AGS to meet electricity power production requirements (BASE Scenario).

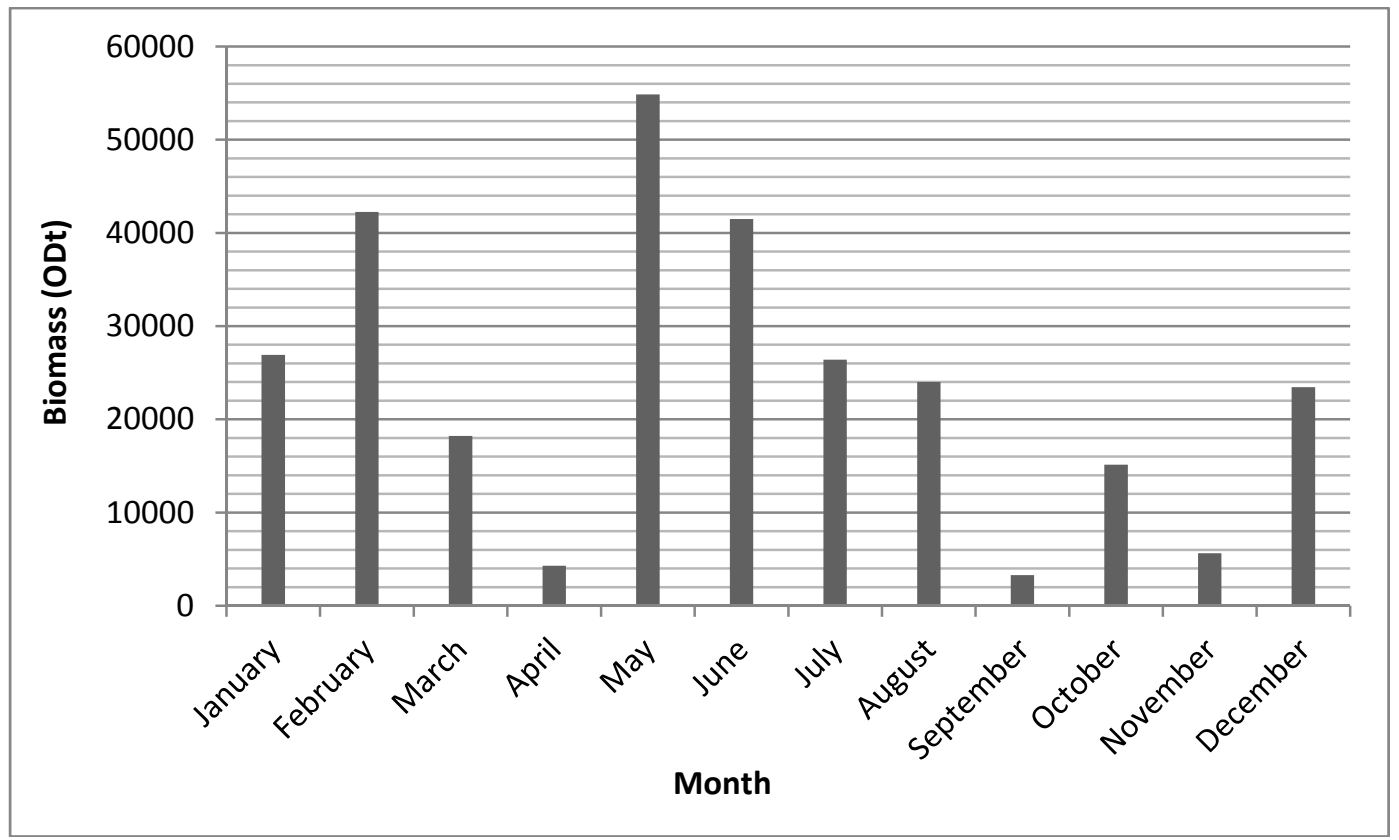


The total monthly woody biomass procurement cost for electricity production at the AGS ranges from \$0.2 million (September) to \$3.4 million (May) (Figure 6). The median and average monthly woody biomass procurement costs are $\$ 1.46$ million and $\$ 1.47$ million, respectively (Figure 6). The monthly feedstock cost per unit electricity production ranges from $32.77 \$ \cdot \mathrm{MWh}^{-1}$ (January) to 36.10 $\$ \cdot \mathrm{MWh}^{-1}$ (November). The monthly median feedstock cost per unit electricity is $35.29 \$ \cdot \mathrm{MWh}^{-1}$.

Figure 6. Monthly total procurement cost of woody biomass feedstock for electricity production at the AGS (BASE Scenario).

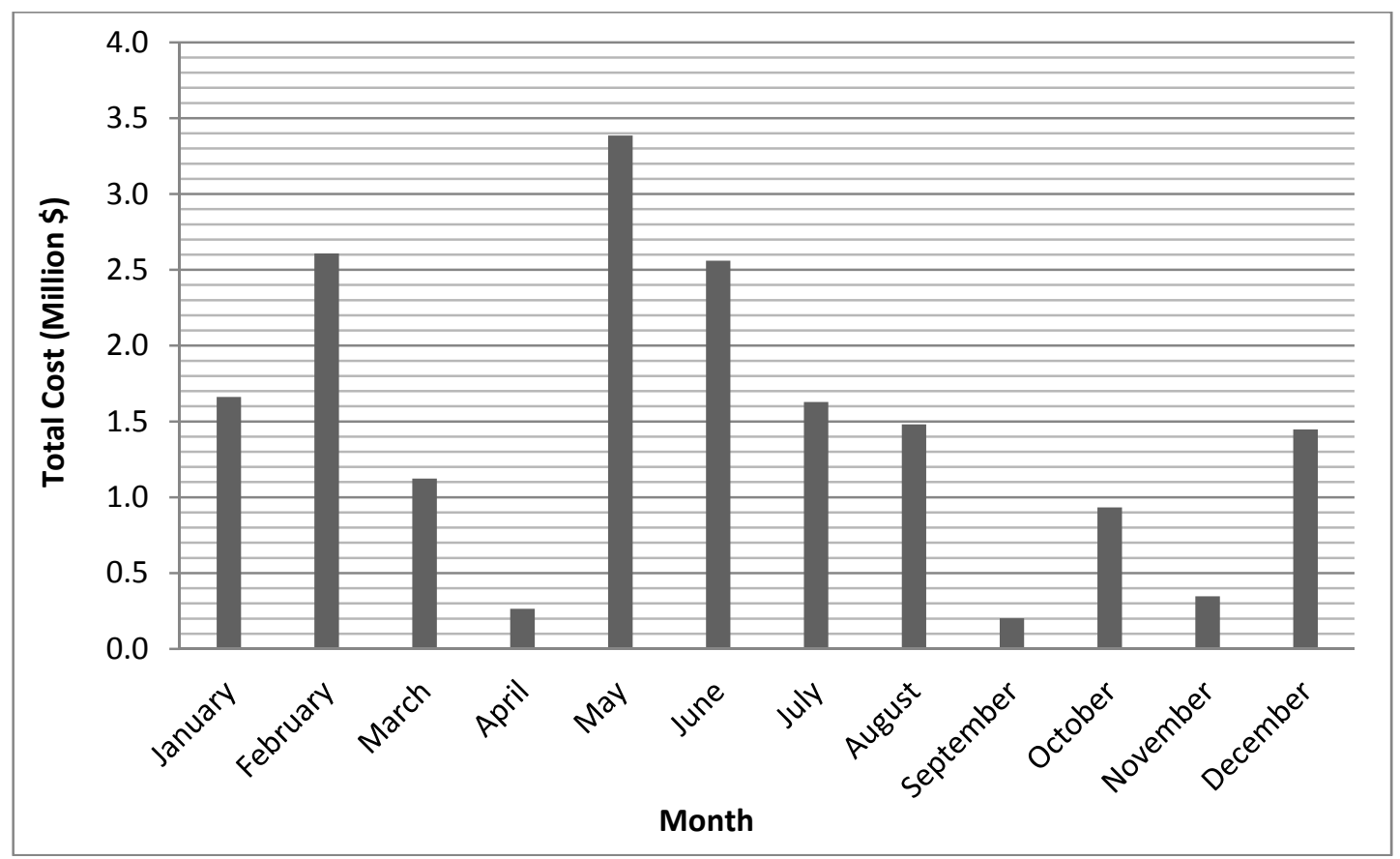

In order to produce 0.51 million MWh of electricity annually at the AGS, a total 0.29 million ODt of woody biomass is required, with a total annual cost of $\$ 17.64$ million and average per unit biomass procurement cost of $61.71 \$ \cdot \mathrm{ODt}^{-1}$, respectively (Table 3 ). The average feedstock cost is $34.81 \$ \cdot \mathrm{MWh}^{-1}$, which is the weighted average based on monthly power produced/biomass used and not just a straight average of the 12 months (Table 3). The lower amounts of monthly total woody biomass requirements and lower total monthly costs in some months (such as April, September and November) are due to the fact that the AGS produced lower amounts of electricity in those months (Figures 3, 5 and 6).

It is observed that at first the model selects the cells, which are closer to the AGS, and in later months farther cells are selected. The behaviour of the model is consistent with an a priori hypothesis of mode of biomass collection or procurement. The cells which are located at longer distances from the AGS (Lake Nipigon, Ogoki and Red Lake) are not utilized by the model for woody biomass procurement, as it is not economically feasible to transport biomass over such long distances. 
Table 3. Sensitivity analyses on the total amount of annual biomass harvesting, total biomass procurement cost, unit biomass procurement cost and the unit electricity production cost. Numbers in brackets represent \% change from the BASE scenario.

\begin{tabular}{|c|c|c|c|c|c|}
\hline Scenario & 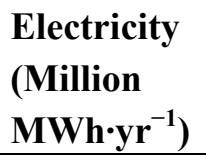 & 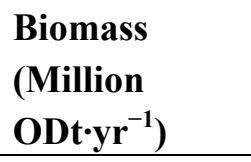 & $\begin{array}{l}\text { Total cost } \\
\left(\text { Million } \$ \cdot \mathbf{y r}^{-1}\right)\end{array}$ & $\operatorname{Cost}\left(\$ \cdot \mathrm{ODt}^{-1}\right)$ & $\operatorname{Cost}\left(\$ \cdot M W h^{-1}\right)$ \\
\hline BASE & 0.51 & 0.29 & 17.64 & 61.71 & 34.80 \\
\hline HFIA & 0.51 & 0.29 & $17.55(-0.5 \%)$ & $61.39(-0.5 \%)$ & $34.62(-0.5 \%)$ \\
\hline HFIB & 0.51 & 0.29 & $17.47(-1 \%)$ & $61.11(-1 \%)$ & $34.46(-1 \%)$ \\
\hline HFDA & 0.51 & 0.29 & $17.74(+0.6 \%)$ & $62.06(+0.6 \%)$ & $34.99(+0.6 \%)$ \\
\hline HFDB & 0.51 & 0.29 & $17.86(+1.2 \%)$ & $62.46(+1.2 \%)$ & $35.22(+1.2 \%)$ \\
\hline CEIA & 0.51 & $0.26(-9.1 \%)$ & $15.96(-9.5 \%)$ & $61.39(-0.5 \%)$ & $31.47(-9.5 \%)$ \\
\hline CEIB & 0.51 & $0.24(-16.7 \%)$ & $14.56(-17.5 \%)$ & $61.11(-1 \%)$ & $28.72(-17.5 \%)$ \\
\hline CEDA & 0.51 & $0.32(+11.1 \%)$ & $19.71(+11.7 \%)$ & $62.06(+0.6 \%)$ & $38.88(+11.7 \%)$ \\
\hline CEDB & 0.51 & $0.36(+25 \%)$ & $22.32(+26.5 \%)$ & $62.46(+1.2 \%)$ & $44.03(+26.5 \%)$ \\
\hline MCIA & 0.51 & $0.29(+1.3 \%)$ & $19.24(+9.1 \%)$ & $66.41(+7.6 \%)$ & $37.95(+9.1 \%)$ \\
\hline MCIB & 0.51 & $0.29(+3 \%)$ & $21.15(+19.9 \%)$ & $71.86(+16.5 \%)$ & $41.72(+19.9 \%)$ \\
\hline MCDA & 0.51 & $0.28(-1.2 \%)$ & $16.28(-7.7 \%)$ & $57.62(-6.6 \%)$ & $32.12(-7.7 \%)$ \\
\hline MCDB & 0.51 & $0.28(-2.1 \%)$ & $15.12(-14.3 \%)$ & $54.02(-12.4 \%)$ & $29.81(-14.3 \%)$ \\
\hline PCIA & 0.51 & 0.29 & $18.95(+7.4 \%)$ & $66.28(+7.4 \%)$ & $37.38(+7.4 \%)$ \\
\hline PCIB & 0.51 & 0.29 & $20.25(+14.8 \%)$ & $70.81(+14.8 \%)$ & $39.93(+14.8 \%)$ \\
\hline PCDA & 0.51 & 0.29 & $16.32(-7.5 \%)$ & $57.09(-7.5 \%)$ & $32.19(-7.5 \%)$ \\
\hline PCDB & 0.51 & 0.29 & $14.99(-15 \%)$ & $52.43(-15 \%)$ & $29.57(-15 \%)$ \\
\hline
\end{tabular}

Note: Abbreviation of different scenarios of the model: BASE $=$ Business as usual scenario of the model, and in other scenarios the parameter values change in relation with this scenario; HFIA = In this scenario HF increased by $10 \%$ from BASE scenario; HFIB $=$ HF increased by $20 \%$; HFDA $=$ HF decreased by $10 \%$; $\mathrm{HFDB}=\mathrm{HF}$ decreased by $20 \%$; CEIA $=\mathrm{CE}$ increased by $10 \%$; CEIB $=\mathrm{CE}$ increased by $20 \%$; CEDA $=\mathrm{CE}$ decreased by $10 \%$; $\mathrm{CEDB}=\mathrm{CE}$ decreased by $20 \%$; MCIA $=\mathrm{MC}$ increased by $10 \%$; $\mathrm{MCIB}=\mathrm{MC}$ increased in $20 \%$; $\mathrm{MCDA}=\mathrm{MC}$ decreased by $10 \%$; $\mathrm{MCDB}=\mathrm{MC}$ decreased by $20 \%$; PCIA $=\mathrm{PR}$ and $\mathrm{PU}$ increased by $10 \%$; $\mathrm{PCIB}=\mathrm{PR}$ and $\mathrm{PU}$ increased by $20 \%$; $\mathrm{PCDA}=\mathrm{PR}$ and $\mathrm{PU}$ decreased by $10 \%$; $\mathrm{PCDB}=\mathrm{PR}$ and $\mathrm{PU}$ decreased by $20 \%$.

The results of the 16 sensitivity analyses are shown in Table 3 . The HF and procurement cost were found to be inversely related: i.e., when HF increases the procurement cost decreases and vise-versa. In HFIA and HFIB scenarios the total woody biomass procurement cost, per unit woody biomass procurement cost and per unit electricity production cost all decrease by $0.5 \%$ and $1 \%$, respectively in relation to an HF increase by $10 \%$ and $20 \%$, respectively. On the other hand in HFDA and HFDB scenarios the total woody biomass procurement cost, the per unit woody biomass procurement cost and the feedstock cost per MWh all increase by $0.6 \%$ and $1.2 \%$, respectively in relation to an HF decrease by $10 \%$ and $20 \%$, respectively. The electricity production cost decreases with an increase in HF because more woody biomass could be harvested from nearby forest cells that further reduces the transportation cost [42]. However, increases or decreases in HF by up to $20 \%$ from the BASE scenario of $67 \%$ had a limited impact on procurement and feedstock cost per MWh. The results of the studies conducted by Cundiff [34] and Sokhansanj and Fenton [69] support the results of this study. 
The $\mathrm{CE}$ and procurement cost are also inversely related: i.e., when $\mathrm{CE}$ increases the procurement cost decreases and vise-versa. In CEIA and CEIB, the amount of woody biomass harvested, the total woody biomass procurement cost, the per unit woody biomass procurement cost and the feedstock cost per MWh decrease by $(9.1 \%, 9.5 \%, 0.5 \%$ and $9.5 \%)$ and $(16.7 \%, 17.5 \%, 1 \%$ and $17.5 \%)$ in relation to a CE increase by $10 \%$ and $20 \%$, respectively. Whereas in CEDA and CEDB, the amount of woody biomass harvested, the total woody biomass procurement cost, the per unit woody biomass procurement cost and the feedstock cost per MWh cost increase by $(11.1 \%, 11.7 \%, 0.6 \%$ and $11.7 \%)$ and $(25 \%, 26.5 \%, 1.2 \%$ and $26.5 \%)$ in relation to a CE decrease by $10 \%$ and $20 \%$, respectively. Therefore, with changes in $\mathrm{CE}$, though the changes in the per unit woody biomass procurement cost is minimal, the changes in the amount of woody biomass harvested, the total woody biomass procurement cost and the feedstock cost per MWh are very high. This is because, with higher CE, the required amount of woody biomass feedstock to produce the same power at the AGS is reduced, and hence the feedstock cost per MWh becomes lower [5,42,70]. Therefore, there is high potential for cost savings through efforts to increase CE.

The MC and procurement cost are positively related: i.e., when $\mathrm{MC}$ increases the procurement cost increases and vice-versa. In MCIA and MCIB, the amount of woody biomass harvested, the total woody biomass procurement cost, the per unit woody biomass procurement cost and the feedstock cost per MWh increase by $(1.3 \%, 9.1 \%, 7.6 \%$ and $9.1 \%)$ and $(3 \%, 19.9 \%, 16.5 \%$ and $19.9 \%)$ in relation to a MC increase by $10 \%$ and $20 \%$, respectively. Whereas, in MCDA and MCDB, the amount of woody biomass harvesting, the total woody biomass procurement cost, the per unit woody biomass procurement cost and the feedstock cost per MWh decrease by $(1.2 \%, 7.7 \%, 6.6 \%$ and $7.7 \%)$ and $(2.1 \%, 14.3 \%, 12.4 \%$ and $14.3 \%)$ in relation to a MC decrease by $10 \%$ and $20 \%$, respectively. With a change in $\mathrm{MC}$, the changes in the total woody biomass procurement cost, the per unit woody biomass feedstock procurement cost and the feedstock cost per MWh are very high, with increases in MC having a higher impact than decreases in MC. This is because, with higher MC, the net heat value decreases at a higher rate in woody biomass and a higher volume of woody biomass is required for producing the same amount of electricity and eventually the cost of electricity increases [5,70,71]. Efforts to decrease MC and control it at an acceptable level (e.g., $<30 \%$ green weight basis) have high potential for reducing biomass procurement and electricity generating costs [72].

The PC and procurement cost are positively related: i.e., when PC increases the procurement cost increases and when PC decreases the procurement cost also decreases. In PCIA and PCIB, the total woody biomass procurement cost, the per unit woody biomass procurement cost and the feedstock cost per MWh all increase by $7.4 \%$ and $14.8 \%$ in relation to a PC increase by $10 \%$ and $20 \%$, respectively. Whereas, in PCDA and PCDB, the total woody biomass procurement cost, the per unit woody biomass procurement cost and the feedstock cost per MWh all decrease by $7.5 \%$ and $15 \%$ in relation to a PC decrease by $10 \%$ and $20 \%$, respectively. With a change in PC, the change in the total woody biomass procurement cost, the per unit woody biomass procurement cost and the feedstock cost per MWh are very high. Previous studies conducted by Berndes et al. [5], Tatsiopoulos and Tolis [73], and Sokhansanj and Fenton [69] show similar results. Research and efforts to reduce biomass processing costs also have high potential for reducing biomass procurement and electricity generating costs.

Scenario analyses of this integrated NLDP model provide interesting information on where to focus further research in the woody biomass procurement chain for bioenergy production to reduce woody 
biomass procurement and electricity generating costs: i.e., on appropriate harvesting factor (HF), managing moisture content (MC), improving the woody biomass to bioenergy conversion efficiency (CE) and controlling processing costs (PC). Procurement cost and HF were found to be inversely related: i.e., when HF increases the procurement cost decreases and vise-versa. The $\mathrm{CE}$ and procurement cost were also inversely related: i.e., when $\mathrm{CE}$ increases the procurement cost decreases and vise-versa. Therefore, there is high potential for cost savings through efforts to increase CE, and decrease PC and MC.

\section{Conclusions}

The complexities of procuring woody biomass feedstock to the AGS in NWO in the most cost effective way are handled by developing a non-linear dynamic programming model. The model provides a global optimal solution for quantity and types of woody biomass selected by minimizing the costs of harvesting, processing and transportation. The model also shows the potential to analyze the effects of changes in important parameters and choice variables on biomass feedstock cost, thereby providing important information for decision support to reduce the procurement costs over time. The conversion efficiency was found to be the most sensitive followed by the moisture content, whereas the harvesting factor showed the least sensitivity.

This is the first optimization model of its kind for planning the logistics of woody biomass procurement for conversion to bioenergy in this region, and as such has important policy implications for designing optimal supply chains under dynamic operational frameworks. This model can be used for optimizing the feedstock procurement of any biomass-based power plant, provided real data related to supply of biomass and road network are available. One of the limitations of this study is the assumption of availability of under-utilized woody biomass. Although, conservative estimates have been used in this study, this limitation can be overcome by the availability of enhanced forest inventory data in the future. The performance of the model could also be further improved by incorporating data related to different tree species, forest types, moisture content, heat values, harvesting systems, storage technique, and variations in the amount of seasonal and weekly power generation. Future versions of this model should reflect these improvements by incorporating new information and will help in developing an integrated decision support system for bioenergy production in NWO.

\section{Acknowledgements}

We acknowledge the financial support from the Ontario Ministry of Energy and Infrastructure through the Ontario Centres of Excellence, NSERC Strategic Network on VCO, Abitibi-Bowater Inc., and Thunder Bay Community Economic Development Commission to pursue this study. We are thankful to Lakehead University, Confederation College, FPInnovations Forest Operations Division, Lac Des Mille Lac First Nation, Buchanan Group and Ontario Ministry of Natural Resources for further support. 


\section{References}

1. Ediger, V.S.; Kentel, E. Renewable energy potential as an alternative to fossil fuels in Turkey. Energy Conver. Manag. 1999, 40, 743-755.

2. Ushiyama, I. Renewable energy in Japan. Renew. Energy 1999, 16, 1174-1179.

3. Nagel, J. Biomass in energy supply, especially in the state of Brandeburg, Germany. Ecol. Eng. 2000, 16, 103-110.

4. Pari, L. Energy production from biomass: The case of Italy. Renew. Energy 2001, 22, 21-30.

5. Berndes, G.; Hoogwijk, M.; van den Broek, R. The contribution of biomass in the future global energy supply: A review of 17 studies. Biomass Bioenergy 2003, 25, 1-28.

6. Gan, J.; Smith, C.T. Availability of logging residues and potential for electricity production and carbon displacement in the USA. Biomass Bioenergy 2006, 30, 1011-1020.

7. Bradley, D. Canada Biomass-Bioenergy Report. Climate Change Solutions-IEA Bioenergy Task 40-Biotrade; Canada Country Report; 2006. Available online: http://bioenergytrade.org/ t40reportspapers/0000009a190b6270c/0000009b0808ec301.html (accessed on 10 September 2010).

8. Alam, M.B.; Pulkki, R.; Shahi, C. Road network optimization model for supplying wood biomass feedstock for energy production in northwestern Ontario. Open For. Sci. J. 2012, 5, 9-22.

9. Sygration. Ontario Electricity Reports and Tools: Current Ontario Generator Output; 2011. Available online: https://www.sygration.com/ (accessed on 10 January 2011).

10. Forest BioProducts Inc. An Assessment of the Viability of Exploiting Bio-Energy Resources Accessible to the Atikokan Generating Station in Northwestern Ontario; Forest BioProducts Inc.: Sault Ste. Marie, Canada, 2006.

11. McCarthy, S. Ottawa Takes Aim at Coal-Fired Power Plants. Toronto Globe and Mail International: Toronto, Canada; 29 April, 2009.

12. Chauhan, S.S.; Frayret, J.M.; LeBel, L. Multi-commodity supply network planning in the forest supply chain. Eur. J. Oper. Res. 2009, 196, 688-696.

13. Rönnqvist, M. Optimization in forestry. Math. Program. B 2003, 97, 267-284.

14. Caputo, A.; Palumbo. M.; Pelagagge, P.; Scacchia, F. Economics of biomass energy utilization in combustion and gasification plants: Effects of logistics variables. Biomass Bioenergy 2005, 28, $35-51$.

15. Bredström, D.; Lundgren, J.T.; Rönnqvist, M.; Carlsson, D.; Mason, A. Supply chain optimization in the pulp mill industry IP models, column generation and novel constraint branches. Eur. J. Oper. Res. 2004, 156, 2-22.

16. Mitchell, C. Development of decision support systems for bioenergy applications. Biomass Bioenergy 2000, 18, 265-278.

17. Freppaz, D.; Minciardi, R.; Robba, M.; Rovatti, M.; Sacile, R.; Taramasso, A. Optimizing forest biomass exploitation for energy supply at a regional level. Biomass Bioenergy 2004, 26, 15-25.

18. Gronalt, M.; Rauch, P. Designing a regional forest fuel supply network. Biomass Bioenergy 2007, 31, 393-402.

19. Dunnet, A.J.; Adjiman, C.S.; Nilay, S. A spatially explicit whole system model of the lignocellulosic bioethanol supply chain: An assessment of decentralized processing potential. Biotechnol. Biofuels 2008, 1, 1-13. 
20. Sylvain, L.; Dagmar, S.; Erik, D.; Erwin, S.; Michael, O. Optimal location of wood gasification plants for methanol production with heat recovery. Int. J. Energy Res. 2008, 32, 1080-1091.

21. Rentizelas, A.A.; Tatsiopoulos, I.P.; Tolis, A. An optimization model for multi-biomass tri-generation energy supply. Biomass Bioenergy 2009, 33, 223-233.

22. Manomet Center for Conservation Sciences (MCCS). Biomass Sustainability and Carbon Policy Study; Report to the Commonwealth of Massachusetts Department of Energy Resources; Walker, T., Ed.; Natural Capital Initiative Report NCI-2010-03; Manomet Center for Conservation Sciences: Brunswick, ME, USA, 2010.

23. Cundiff, J.S.; Dias, N.; Sherali, H.D. A linear programming approach for designing a herbaceous biomass delivery system. Bioresour. Technol. 1997, 59, 47-55.

24. Kong, X.Q.; Wang, R.Z.; Huang, X.H. Energy optimization model for a CCHP system with available gas turbines. Appl. Therm. Eng. 2005, 25, 377-391.

25. Ren, H.; Zhou, W.; Nakagami, K.; Gao, W. Integrated design and evaluation of biomass energy system taking into consideration demand side characteristics. Energy 2010, 35, 2210-2222.

26. Nagel, J. Determination of an economic energy supply structure based on biomass using a mixed-integer linear optimisation model. Ecol. Eng. 2000, 16, 91-102.

27. Gunnarsson, H.; Roennqvist, M.; Lundgren, J.T. Production, manufacturing and logistics: Supply chain modeling of forest fuel. Eur. J. Oper. Res. 2004, 158, 103-123.

28. Wu, J.; Wang, J.; McNeel, J. Economic modeling of woody biomass utilization for bioenergy and its application in central Appalachia, USA. Can. J. For. Res. 2011, 41, 165-179.

29. Mas, M.D.; Giarola, S.; Zamboni, A.; Bezzo, F. Capacity Planning and Financial Optimization of the Bioethanol Supply Chain under Price Uncertainty. In Computer Aided Chemical Engineering, Proceedings of the 20th European Symposium on Computer Aided Process EngineeringESCAPE20; Pierucci, S., Buzzi Ferraris, G., Eds.; Elsevier: Amsterdam, The Netherlands, 2010.

30. Kim, J.; Realff, M.J.; Lee, J.H.; Whittaker, C.; Furtner, L. Design of biomass processing network for biofuel production using an MILP model. Biomass Bioenergy 2011, 35, 853-871.

31. Kaylen, M.; Van Dyne, D.L.; Choi, Y.S.; Blasé, M. Economic feasibility of producing ethanol from lignocellulosic feedstocks. Bioresour. Technol. 2000, 72, 19-32.

32. Jenkins, B.M.; Arthur, J.F.; Miller, G.E.; Parsons, P.S. Logistics and economics of biomass utilization. Trans. Am. Soc. Agric. Eng. 1984, 27, 1898-1904.

33. Adams, D.; Adams, R.; Callaway, J.M.; Chang, C.; McCarl, B.A. Sequestering carbon on agricultural land: A preliminary analysis of social costs and impacts on timber markets. Contemp. Policy Issues 1993, 11, 76-87.

34. Cundiff, J.S. Simulation of five large round bale harvesting systems for biomass. Bioresour. Technol. 1997, 56, 77-82.

35. Mantovani, B.; Gibson, H. A simulation model for analysis of harvesting and transport costs for biomass based on geography, density and plant location. Anal. Agric. Energy Syst. 1992, 5, 253-280.

36. Huisman, W. Logistics of Harvest of Miscanthus sinensis Giganteus. In Proceedings of the 8th European Biomass Conference, Pergamon, Oxford, UK, 1994; Chartier, P., Beenackers, A.A.C.M., Grassi, G., Eds.; pp. 361-371. 
37. De Mol, R.M.; Jogems, M.A.H.; van Beek, P.; Gigler, J.K. Simulation and optimization of the logistics of biomass fuel collection. Neth. J. Agric. Sci. 1997, 45, 219-228.

38. Becher S.; Kaltschmitt, M. Logistic Chains of Solid Biomass-Classification and Chain Analysis. In Proceedings of the 8th European Biomass Conference, Pergamon, Oxford, UK, 1994; Chartier, P., Beenackers, A.A.C.M., Grassi, G., Eds.; pp. 401-408.

39. Pulkki, R. Role of supply chain management in the wise use of wood resources. South. Afr. J. 2001, 191, 89-95.

40. Kumar, A.; Flynn, P.C.; Sokhansanj, S. Biopower generation from mountain pine beetle infested wood in Canada: An economical opportunity for greenhouse gas mitigation. Renew. Energy 2008, $33,1354-1363$.

41. Alam, M.B.; Pulkki, R.; Shahi, C.; Upadhyay, T. Wood Biomass Procurement for Bioenergy Production in Northwestern Ontario: A Decision Support System Based on Mixed Integer Programming Model. In Proceedings of International Conference on Logging and Industrial Ecology, Nanjing, China, 3-5 November, 2009.

42. Alam, M.B.; Shahi, C.; Pulkki, R. Wood Biomass Supply Model for Bioenergy Production in Northwestern Ontario. In Proceedings of Renewable Energy Technology (ICDRET): 1st International Conference on the Developments in Renewable Energy Technology, Dhaka, Bangladesh, 17-19 December, 2009.

43. Sowlati, T. Forest Products and Forest Biomass Transportation and Logistics. FORAC. 2009. Available online: http://www.forac.ulaval.ca (accessed on 28 June 2010).

44. Sokhansanj, S.; Kumar, A.; Turhollow, A.F. Development and implementation of integrated biomass supply analysis and logistics model (IBSAL). Biomass Bioenergy 2006, 30, 838-847.

45. Alam, M.B.; Pulkki, R.; Shahi, C. Wood biomass availability for bioenergy production using forest depletion spatial data in northwestern Ontario. Can. J. For. Res. 2012, 42, 506-516.

46. Graham, R.L.; English, B.C.; Noon, C.E. A geographic information system-based modeling system for evaluating the cost of delivered energy crop feedstock. Biomass Bioenergy 2000, 18, 309-329.

47. Frombo, F.; Minciardi, R.; Robba, M.; Rosso, F.; Sacile, R. Planning woody biomass logistics for energy production: A strategic decision model. Biomass Bioenergy 2009, 33, 372-383.

48. Tittmann, P.W.; Parker, N.C.; Hart, Q.J.; Jenkins, B.M. A spatially explicit techno-economic model of bioenergy and biofuels production in California. J. Transp. Geogr. 2010, 18, 715-728.

49. Noon, C.E.; Daly, M.J. GIS-based resource assessment with BRAVO. Biomass Bioenergy 1996, 10, 101-109.

50. Voivontas, D.; Assimacopoulos, D.; Koukios, E. Assessment of biomass potential for power production: A GIS based method. Biomass Bioenergy 2001, 20, 101-112.

51. Ranta, T. Logging residues from regeneration fellings for biofuel production-A GIS-based availability analysis in Finland. Biomass Bioenergy 2005, 28, 171-182.

52. Geijzendorffer, R.; Annevelink, E.; Elbersen, B.; Smidt, R.; de Mol, R.M. Application of A GIS-Bioloco Tool for the Design and Assessment of Biomass Delivery Chains. In Proceedings of 16th European Biomass Conference \& Exhibition, Valencia, Spain, 2-6 June, 2008.

53. Sylvain, L.; Erwin, S.; Michael, O.; Keywan, R. Methanol production by gasification using a geographically explicit model. Biomass Bioenergy 2009, 33, 745-751. 
54. Abitibi-Bowater Inc. Shape Files of FRI Data (Forests, Roads and Lake Layers), Forest Depletion, and Forest Management Planning of Crossroute Forest, Dog River Matawin Forest, Black Sturgeon Forest, English River Forest, and Spruce River Forest Management Units. Personal Communication with Martin Kaiser, R.P.F., Manager, Strategic Business Development, Fibre Resources Ontario, Thunder Bay, Canada, 2009.

55. Greenmantle Forest Inc. Shape files of FRI Data (Forests, Roads and Lake Layers), Forest Depletion, and Forest Management Planning of Lakehead Forest Management Unit. Personal Communication with Dave MacIsaac, Area Forester, Thunder Bay, Ontario, 2009.

56. Green Forest Management Inc. PDF Files of Block Area and Timber Volumes and Shape Files of FRI Data (Forests, Roads and Lake Layers), Forest Depletion, and Forest Management Planning of Sapawe Forest Management Unit. Personal Communication with Richard Shwedack, R.P.F., Thunder Bay, Ontario, Canada, 2009.

57. Land Information Ontario (LIO). Geographic Information System (GIS) data for the Forest Management Units (FMUs) of Northwestern Ontario. Personal Communication with Land Information Ontario (LIO), Ontario, Canada, 2010.

58. Nichols, S.J.; Pulkki, R.E.; Ackerman, P.A. Provincial road condition and roundwood transport in South Africa. South. Afr. For. J. 2006, 207, 55-61.

59. ESRI. ArcGIS 9.3 Desktop Help. Environmental Systems Research Institute (ESRI), Inc. 2010. Available online: http://webhelp.esri.com/arcgisdesktop/9.3/index.cfm? (accessed on 15 November 2010).

60. Ministry of Transportation Ontario (MTO). Vehicle Weight and Dimension Reforms in Ontario. Ministry of Transportation Ontario, Canada. 2012. Available online: http://www.mto.gov.on.ca/ english/trucks/vwd/reforms.shtml (accessed on 20 July 2012).

61. Ride, K. Current and Short-Term Status of Forest Biofibre Supply and Utilization in Ontario; Ontario Ministry of Natural Resources: Thunder Bay, Canada, 2008.

62. Ride, K. Forest Biofibre Outlook in Ontario and the Northwest Region; Ontario Ministry of Natural Resources: Thunder Bay, Canada, 2008.

63. Reynolds, R.; Cormier, D.; Ryans, M. Feasibility of Forest Feedstock for Bioenergy in Northwestern Ontario. Contract Report CR-0366-3, October 2008, FPInnovations FERIC Division: Pointe-Claire, Canada, 2008.

64. Ontario Ministry of Natural Resources (OMNR). Forest Information Manual 2007: Forest Resources Inventory Technical Specifications; Technical Series, 1 June 2007; Ontario Ministry of Natural Resources: Ontario, Canada, 2007.

65. Ontario Ministry of Natural Resources (OMNR). Scaling Manual. Ontario Ministry of Natural Resources, Ontario, Canada. 2007. Available online: http:/www.web2.mnr.gov.on.ca/mnr/forests/ forestdoc/reg_manuals/manuals/scaling/file_one.pdf (accessed on 19 July 2011).

66. Gautam, S.; Pulkki, R.; Shahi, C.; Leitch, M. Economic and energy efficiency of salvaging biomass from wildfire burnt areas for bioenergy production in northwestern Ontario: A case study. Biomass Bioenergy 2010, 34, 1562-1572.

67. Hosegood, S.I. Fuel characteristics of northwestern Ontario tree species and their components. M.Sc. Thesis, Lakehead University, Thunder Bay, Canada, 2010; pp. 1-133. 
68. Gautam, S.; Pulkki, R.; Shahi, C.; Leitch, M. Fuel quality changes in full tree logging residue during storage in roadside slash piles in Northwestern Ontario. Biomass Bioenergy 2012, 42, 43-50.

69. Sokhansanj, S.; Fenton, J. Cost Benefit of Biomass Supply and Pre-Processing; Technical Report from BIOCAP, Kingston, Canada, 2006. Available online: http://www.biocap.ca/rif/report/ Sokhansanj_S.pdf (accessed on 12 January 2011).

70. Koppejan, J. Fuel Storage, Handling and Preparation and System Analysis for Biomass Combustion Technologies. In Proceedings of 2007 European Biomass Conference, Berlin, Germany, 7-11 May, 2007.

71. Nurmi, J. The storage of logging residue for fuel. Biomass Bioenergy 1999, 17, 41-47.

72. Gautam, S. Assessment of Fuel Quality Changes during Storage of Biofibre and Its Effect on Cost. M.Sc. Thesis, Lakehead University, Thunder Bay, Canada, 2010.

73. Tatsiopoulos, I.; Tolis, A. Economic aspects of the cotton-stalk biomass logistics and comparison of supply chain methods. Biomass Bioenergy 2003, 24, 199-214.

(C) 2012 by the authors; licensee MDPI, Basel, Switzerland. This article is an open access article distributed under the terms and conditions of the Creative Commons Attribution license (http://creativecommons.org/licenses/by/3.0/). 